\title{
White Matter $\beta$-Amyloid Precursor Protein Immunoreactivity in Autopsied Subjects With and Without COVID-19
}

Thomas G. Beach ${ }^{\mathrm{a}}$, Michael DeTure ${ }^{\mathrm{b}}$, Jessica E. Walker ${ }^{\mathrm{a}}$ Richard Arcea, Michael J. Glass ${ }^{\text {a }}$, Lucia I. Sue ${ }^{a}$, Anthony J. Intorcia ${ }^{a}$, Courtney M. Nelsona, Katsuko E. Suszczewicz ${ }^{\mathrm{a}}$, Claryssa I. Borja ${ }^{\mathrm{a}}$, Geidy E. Serrano ${ }^{\mathrm{a}}$ and Dennis W. Dickson ${ }^{\mathrm{b}}$ aBanner Sun Health Research Institute, Sun City, AZ

bMayo Clinic College of Medicine, Mayo Clinic Florida, Jacksonville, FL

Correspondence: Thomas G. Beach, Banner Sun Health Research Institute 10515 West Santa Fe Drive, Sun City, AZ 85351

Telephone: 623-832-5643

Fax: 623-815-2960

thomas.beach@bannerhealth.com 


\section{ABSTRACT}

The coronavirus SARS-CoV-2 causes COVID-19, a predominantly respiratory disease that has been reported to be associated with numerous neurological signs, symptoms and syndromes. More than 20 published studies have used RT-PCR methods to determine viral SARS-CoV-2 genomic presence in postmortem brain tissue and the overall impression is that viral brain invasion is relatively uncommon and occurs in low copy numbers, supporting indirect mechanisms as the cause of most neurological phenomena. Hypoxic-ischemic brain injury and stroke are one such possible indirect mechanism, as acute ischemia or stroke concurrence with COVID-19 has been reported as being $0.5 \%$ to $20 \%$. Immunohistochemical stains for $\beta$-amyloid precursor protein (APP) have been suggested to be a "signature" change of hypoxic leukoencephalopathy or COVID-19 brain disease, although prior reports have not had a non-COVID-19 control group. We therefore compared the prevalence and intensity of white matter APP staining in the brains of subjects dying with and without COVID-19. Clinical and neuropathological results, including semi-quantitative assessment of the density of white matter APP staining, were compared between 20 COVID-19 cases and 20 pre-COVID-19 autopsy cases, including 10 cases with autopsy-proven non-COVID-19 pneumonia and 10 cases without pneumonia. Positive APP white matter staining in at least one of the two brain regions (precentral gyrus and cingulate gyrus) studied was not significantly more common in COVID-19 vs controls (14/20 vs 12/20). Comparing density scores from both brain regions combined, the mean scores for COVID-19 cases were higher than those for controls of both types together but not significantly different when restricting to controls with pneumonia. Among control cases, cases with pneumonia had significantly higher scores. The presence or absence of a major neuropathologically-defined neurodegenerative disorder did not significantly affect the APP scores. The major finding is that while APP white matter staining cannot be regarded as a specific marker of COVID-19, as it does not occur with significantly greater probability in in COVID-19 brains as compared to non-COVID-19 brains, it is possible that white matter APP staining, representing acute or subacute axonal damage, may be a common occurrence in the perimortem period, and that it may be more intense in subjects dying with pneumonia, regardless of cause. 


\section{INTRODUCTION}

The coronavirus SARS-CoV-2 (SCV2) has been reported to be associated with numerous neurological signs, symptoms and syndromes, affecting up to $36 \%$ of patients ${ }^{1-10}$. It is not yet determined whether these are due to direct viral action, indirect immune-mediated mechanisms, or to other systemic reactions common to many types of critical illness. COVID-19 is known to be accompanied by coagulopathy, sepsis, autoimmune attack and multiorgan failure ${ }^{11}$. More than 20 published studies have used RT-PCR methods to determine SCV2 genomic presence in postmortem brain tissue ${ }^{11-31}$ and the overall impression is that SCV2 brain invasion is relatively uncommon and that viral copy numbers are generally low, supporting indirect mechanisms as the cause of most neurological phenomena.

Stroke is a disastrous outcome of COVID-19 disease but how often it occurs is difficult to ascertain due to a wide range in rate estimates. Acute ischemia or stroke concurrence with COVID-19 has been reported as between $0.5 \%$ to $20 \%$ while rates of acute brain hemorrhage range from $0.13 \%$ to $9.5 \% 4,5,11,17,18,20,23,25-27,29,30,32$ 54. To date, however, most reports have not had a non-COVID-19 control group. A few clinical studies have compared stroke rates in hospitalized COVID-19 and influenza subjects, finding low but slightly increased rates with COVID-19 ${ }^{49,50}$ (1.6\% vs $0.2 \%$ and $0.9 \%$ vs $0.3 \%$ ) or alternatively, equivalent rates ${ }^{32}$ ( $1.2 \%$ for both). We found, in a study of 691 pre-COVID-19 autopsies, that the prevalence of acute ischemia or infarction did not differ between autopsy-confirmed pneumonia and non-pneumonia cases, both being about $14 \%{ }^{55}$. We suggest that COVID-19 and non-COVID-19 pneumonia may have similar risks for concurrent acute brain infarction when pneumonia is severe enough to cause death. Moreover, acute brain ischemia, infarction or hemorrhage may not be more common in subjects dying of acute pneumonia than in subjects dying without acute pneumonia.

These studies, however, have been based on clinical reports or standard autopsy diagnostic methods, and it is possible that more sensitive methods might be more informative. In particular, immunohistochemical stains for $\beta$-amyloid precursor protein (APP) have been suggested to be a "signature" change of hypoxic leukoencephalopathy or COVID-19 brain disease ${ }^{39,42}$. We therefore compared the prevalence and intensity of white matter APP staining in the brains of subjects dying with and without COVID-19. 


\section{MATERIALS AND METHODS}

\section{Human Subjects and Characterization}

The COVID-19 subjects were derived from Banner Sun Health Research Institute (BSHRI) in Sun City, Arizona $(n=10)$, or from the Mayo Clinic in Jacksonville, Florida $(n=10)$. All subjects had been consented for autopsy and subsequent research studies with approval by Institutional Review Boards (Western IRB \# 1132516; Mayo Clinic Florida Brain Bank IRB \# 15-009452).

Clinical and neuropathological results for the 20 COVID-19 cases are described in our prior publication ${ }^{56}$ and are briefly re-summarized in Table 1. All COVID-19 subjects had positive clinical diagnostic test results for SCV2 and all were considered to have died in 2020 as a result of severe COVID-19. An additional 20 cases were chosen from 2018 and 2019 pre-COVID-19 BSHRI autopsies, including 10 cases with autopsy-proven non-COVID-19 pneumonia (all with acute bronchopneumonia) and 10 cases without pneumonia.

For both BSHRI and Mayo Clinic, published diagnostic clinicopathological consensus criteria ${ }^{57-69}$ were used when applicable, incorporating research clinical assessment results as well as pertinent private medical history. The histological sampling and staining incorporated the protocols recommended by the National Institute on Aging and Alzheimer's Association (NIA-AA) ${ }^{67-69}$.

Immunohistochemical staining for APP was performed as previously published ${ }^{70}$ on sections of precentral and cingulate gyrus with underlying white matter. The extent of APP staining was semi-quantitatively graded on a scale of 0-3. To be considered positive there had to be not only increased APP immunoreactivity within axons, but also evidence of focal axonal swelling with or without fragmentation.

Statistical methods included unpaired, two-way t-tests for continuous variables, Kruskal-Wallis and MannWhitney U-tests for ordinal variables and Fisher Exact tests for proportions. The significance level was set at $p$ $<0.05$.

\section{RESULTS}

Table 1 shows basic data for the cases studied. COVID-19 cases were younger (77.5; SD 2.9) than nonCOVID-19 cases (84.0; SD 2.0) but the difference was not significant $(p=0.07)$. Males made up 11/20 and 
medRxiv preprint doi: https://doi.org/10.1101/2021.12.16.21266656; this version posted December 17, 2021. The copyright holder for this

preprint (which was not certified by peer review) is the author/funder, who has granted medRxiv a license to display the preprint in perpetuity.

It is made available under a CC-BY-NC-ND 4.0 International license .

10/20 of the COVID-19 and non-COVID-19 cases, respectively (ns). Both COVID-19 and non-COVID-19

cases had a wide range of neuropathological diagnoses, consistent with their age and derivation from academic centers devoted to the study of neurodegenerative disease.

Table 2 and Figure 1 show results of the APP staining in COVID-19 and non-COVID-19 control cases.

Positive APP white matter staining was seen in at least one of the two brain regions in 14/20 COVID-19 cases and in 12/20 of the non-COVID-19 control cases (ns). Cases were positive in the precentral gyrus in 11/20 COVID-19 and 5/20 control cases (ns) while in the cingulate gyrus the ratios were 12/20 and 10/20, respectively (ns).

Comparing density scores from both brain regions combined, the mean scores for COVID-19 cases were higher than those for controls of both types together ( 0.91 vs 0.44 , Mann-Whitney $p=0.026$ ) but not significantly different ( 0.91 vs $0.60, p=0.35)$ when restricting to controls with pneumonia. Region-specific pairwise scores were not significantly different between COVID-19 and controls of both types (Kruskal-Wallis analysis of variance with subsequent Dunn's Multiple Comparisons pair-wise testing). In both brain regions, scores were not significantly different between BSHRI and Mayo Clinic COVID-19 cases. Among control cases, when considering both brain regions together, cases with pneumonia had significantly higher scores (0.60 vs 0.27 , Mann-Whitney $p=0.044)$.

When cases were divided by presence (those with AD, VaD, HS, PSP, PD, MSA, DLB, DLBD, or FTLDTDP in Table 2) or absence of a major neuropathologically-defined neurodegenerative disorder, there were no significant differences in APP scores between the two groups, either when restricting to one brain region or when scores from both brain regions were combined.

When APP scores from both areas were combined, males had significantly greater scores than females ( 0.89 vs 0.43 , Mann-Whitney $p=0.032$ ). There was no significant correlation (Spearman) between age and APP scores for either brain region.

\section{DISCUSSION}

Immunohistochemical staining of swollen white matter axons for $\beta$-amyloid precursor protein (APP) has been suggested to be a "signature" change of hypoxic leukoencephalopathy or COVID-19 brain disease ${ }^{39,42}$. 
However, these APP-positive features have also been reported in association with a variety of conditions, including human cases and/or animal models of ischemia ${ }^{71,72}$, traumatic brain injury ${ }^{73-75}$, Binswanger's disease or vascular dementia ${ }^{76,77}$, bacterial meningitis ${ }^{78}$, drug abuse ${ }^{79}$ and acute demyelinating diseases ${ }^{80}$. This investigation examined APP staining in the white matter of 20 subjects that died with COVID-19, in comparison with 20 subjects that died prior to the COVID-19 pandemic. The major finding is that APP white matter staining cannot be regarded as a specific marker of COVID-19 as it does not occur with significantly greater probability in in COVID-19 brains as compared to non-COVID-19 brains. Semi-quantitation of the APP staining gives significantly greater scores for COVID-19 brains as compared to non-COVID-19 brains, but not significantly greater relative to the non-COVID-19 subset that died with autopsy-verified pneumonia.

We did not find greater amounts of APP staining in subjects with major neurodegenerative diseases. Males had greater APP staining scores than females. There was no correlation of APP scores with age.

Based on these findings, it is possible that white matter APP staining, representing acute or subacute axonal damage, may be a common occurrence in the perimortem period, and that it may be more intense in subjects dying with pneumonia, regardless of cause.

Biospecimens from the Banner Sun Health Research Institute Brain and Body Donation Program, including those presented in this report, are available to qualified researchers upon request from https://www.brainandbodydonationregistration.org/. 
medRxiv preprint doi: https://doi.org/10.1101/2021.12.16.21266656; this version posted December 17, 2021. The copyright holder for this preprint (which was not certified by peer review) is the author/funder, who has granted medRxiv a license to display the preprint in perpetuity.

It is made available under a CC-BY-NC-ND 4.0 International license .

Table 1. Case data for neuropathologically-diagnosed comorbidities. $B=$ COVID-19 cases derived from BSHRI; $M=$ COVID-19 cases derived from Mayo Clinic; $\mathrm{C}=$ Non-COVID-19 control cases derived from BSHRI; Aclnf = Acute infarctions; $A D=$ Alzheimer's disease; $A D$-insuff $=A D$ changes insufficient for diagnosis; $A R T A G=$ age-related tau astrogliopathy; ASCVD = atherosclerotic cerebrovascular disease; BSLBD = brainstem Lewy body disease; CWMR = cerebral white matter rarefaction; DBS = deep brain stimulator; DLBD = diffuse Lewy body disease; FTLD-TDP = frontotemporal lobar degeneration with TDP-43 proteinopathy; HS = hippocampal sclerosis; LATE = Limbic age-related TDP-43 proteinopathy; OBLBD = olfactory bulb Lewy body disease; $P D=$ Parkinson's disease; $P A R T=$ primary agerelated tauopathy; PNLA = pallido-nigro-Luysian-degeneration; $P S P=$ progressive supranuclear palsy; $T L B D=$ transitional Lewy body disease; $\mathrm{VaD}=$ vascular dementia. Specific ages not given to preserve privacy.

\begin{tabular}{|c|c|c|c|c|c|}
\hline Case & Age & Sex & COVID-19 & $\begin{array}{c}\text { Non-COVID-19 } \\
\text { Pneumonia }\end{array}$ & Neuropathologically-Diagnosed Conditions \\
\hline B1 & 90s & $\mathrm{M}$ & + & - & AD; VaD; HS; PSP; TDP-43 (LATE); ARTAG \\
\hline B2 & $70 s$ & $\mathrm{~F}$ & + & - & PD; AD; ARTAG; DBS \\
\hline B3 & $70 s$ & $\mathrm{M}$ & + & - & PART \\
\hline B4 & $80 \mathrm{~s}$ & $\mathrm{M}$ & + & - & PART \\
\hline B5 & 90s & $\mathrm{M}$ & + & - & AD; CWMR \\
\hline B6 & $70 s$ & $\mathrm{M}$ & + & - & AD; PSP; TLBD; CWMR; TDP-43 (LATE) \\
\hline B7 & $70 s$ & $\mathrm{~F}$ & + & - & PART \\
\hline B8 & $80 s$ & $\mathrm{M}$ & + & - & AD; MSA; TDP-43 (LATE) \\
\hline B9 & $70 s$ & M & + & - & PART \\
\hline B10 & $60 s$ & $\mathrm{~F}$ & + & - & PART \\
\hline M1 & $70 \mathrm{~s}$ & $\mathrm{~F}$ & + & - & AD/TLBD/VaD/CWMR/LATE \\
\hline M2 & $80 \mathrm{~s}$ & $\mathrm{~F}$ & + & - & AD/ASCVD/CWMR \\
\hline M3 & $70 \mathrm{~s}$ & $\mathrm{~F}$ & + & - & DLBD/AD \\
\hline M4 & $80 \mathrm{~s}$ & M & + & - & PSP atypical (PNLA); CWMR; ARTAG \\
\hline M5 & $70 \mathrm{~s}$ & $\mathrm{~F}$ & + & - & PSP/ASCVD/CWMR \\
\hline M6 & $60 \mathrm{~s}$ & M & + & - & $A D$ \\
\hline M7 & $70 \mathrm{~s}$ & $\mathrm{~F}$ & + & - & FTLD-TDP (unusual Type B)/VaD/CWMR \\
\hline M8 & $70 \mathrm{~s}$ & M & + & - & $\mathrm{VaD} / \mathrm{AD}$ \\
\hline M10 & $30 \mathrm{~s}$ & M & + & - & Encephalitis/acute hemorrhagic infarction \\
\hline M11 & $90 \mathrm{~s}$ & $\mathrm{~F}$ & + & - & DLB \\
\hline C1 & $70 \mathrm{~s}$ & M & - & + & PART \\
\hline $\mathbf{C 2}$ & $80 \mathrm{~s}$ & $\mathrm{~F}$ & - & - & $A D$-insuff \\
\hline C3 & $80 \mathrm{~s}$ & $\mathrm{~F}$ & - & + & PART; CWMR \\
\hline C4 & $70 \mathrm{~s}$ & $\mathrm{~F}$ & - & - & ASCVD; CWMR; AD-insuff \\
\hline C5 & $90 \mathrm{~s}$ & M & - & + & AD-insuff; TLBD; ARTAG \\
\hline C6 & $80 \mathrm{~s}$ & $\mathrm{~F}$ & - & - & AD-insuff; LATE \\
\hline C7 & $90 \mathrm{~s}$ & $\mathrm{~F}$ & - & - & AD-insuff; LATE; ARTAG \\
\hline C8 & $90 \mathrm{~s}$ & M & - & + & LATE; PART; ARTAG \\
\hline C9 & $70 \mathrm{~s}$ & $\mathrm{~F}$ & - & - & AD-insuff \\
\hline C10 & $80 \mathrm{~s}$ & M & - & + & AD; CWMR; Aclnf; ARTAG \\
\hline C11 & $70 \mathrm{~s}$ & $M$ & - & + & CWMR; AcInf; PART; ARTAG \\
\hline $\mathbf{C 1 2}$ & $70 \mathrm{~s}$ & $\mathrm{M}$ & - & + & PD; AD; ARTAG \\
\hline C13 & $70 \mathrm{~s}$ & $\mathrm{M}$ & - & + & PD; AD \\
\hline C14 & $80 \mathrm{~s}$ & $\mathrm{~F}$ & - & - & AD; VaD; ASCVD; CWMR; LATE; OBLBD \\
\hline C15 & $80 \mathrm{~s}$ & $\mathrm{M}$ & - & + & AD; LATE; TLBD \\
\hline C16 & $80 \mathrm{~s}$ & $M$ & - & + & PD; CWMR; PART; ARTAG; LATE \\
\hline C17 & $90 \mathrm{~s}$ & $\mathrm{M}$ & - & - & AD; VaD; ASCVD; CWMR; Aclnf; LATE \\
\hline C18 & $90 \mathrm{~s}$ & $\mathrm{~F}$ & - & - & AD; ASCVD; CWMR; ARTAG; LATE \\
\hline C19 & $90 \mathrm{~s}$ & $\mathrm{~F}$ & - & - & AD; PSP; HS; FTLD-TDP; VaD; ASCVD; CWMR; ARTAG \\
\hline $\mathbf{C 2 0}$ & $80 \mathrm{~s}$ & $\mathrm{~F}$ & - & - & AD; CWMR; ARTAG \\
\hline
\end{tabular}


medRxiv preprint doi: https://doi.org/10.1101/2021.12.16.21266656; this version posted December 17, 2021. The copyright holder for this preprint (which was not certified by peer review) is the author/funder, who has granted medRxiv a license to display the preprint in perpetuity.

It is made available under a CC-BY-NC-ND 4.0 International license .

Table 2. Results of semi-quantitation (scale of 0-3) of APP staining in COVID-19 and non-COVID-19 control cases. $\mathrm{PRCG}=$ precentral gyrus; $\mathrm{CING}=$ cingulate gyrus; $\mathrm{CWMR}=$ cerebral white matter rarefaction .

\begin{tabular}{|c|c|c|c|c|}
\hline Case & COVID-19 & $\begin{array}{c}\text { Non-COVID-19 } \\
\text { Pneumonia }\end{array}$ & APP PRCG & APP CING \\
\hline B1 & + & - & 0 & 0 \\
\hline B2 & + & - & 1 & 1 \\
\hline B3 & + & - & 0 & 2 \\
\hline B4 & + & - & 1 & 1 \\
\hline B5 & + & - & 3 & 3 \\
\hline B6 & + & - & 0 & 0 \\
\hline B7 & + & - & 0.5 & 0 \\
\hline B8 & + & - & 3 & 0 \\
\hline B9 & + & - & 1 & 1 \\
\hline B10 & + & - & 0 & 0 \\
\hline M1 & + & - & 0.5 & 1 \\
\hline M2 & + & - & 1 & 1.5 \\
\hline M3 & + & - & 0 & 2 \\
\hline M4 & + & - & 0 & 0 \\
\hline M5 & + & - & 0 & 0 \\
\hline M6 & + & - & 2 & 2 \\
\hline M7 & + & - & 0 & 0 \\
\hline M8 & + & - & 0 & 1 \\
\hline M10 & + & - & 0 & 0 \\
\hline M11 & + & - & 0 & 0 \\
\hline C1 & - & + & 0 & 0 \\
\hline C2 & - & - & 0 & 0 \\
\hline C3 & - & + & 0 & 0 \\
\hline C4 & - & - & 0 & 0 \\
\hline C5 & - & + & 0 & 0 \\
\hline C6 & - & - & 0 & 2 \\
\hline C7 & - & - & 0 & 0 \\
\hline C8 & - & + & 0 & 0 \\
\hline C9 & - & - & 0 & 0 \\
\hline C10 & - & + & 0 & 0 \\
\hline C11 & - & + & 0 & 0 \\
\hline C12 & - & - & 0 & 0 \\
\hline C13 & - & - & 0 & 0 \\
\hline C14 & - & - & 0 & 0 \\
\hline C15 & - & - & 0 & 0 \\
\hline C16 & - & - & 0 & 0 \\
\hline C17 & - & - & 0 & 0 \\
\hline C18 & - & - & 0 & 0 \\
\hline C19 & - & - & 0 & 0 \\
\hline C20 & - & - & 0 & 0 \\
\hline
\end{tabular}


medRxiv preprint doi: https://doi.org/10.1101/2021.12.16.21266656; this version posted December 17, 2021. The copyright holder for this preprint (which was not certified by peer review) is the author/funder, who has granted medRxiv a license to display the preprint in perpetuity.

It is made available under a CC-BY-NC-ND 4.0 International license .
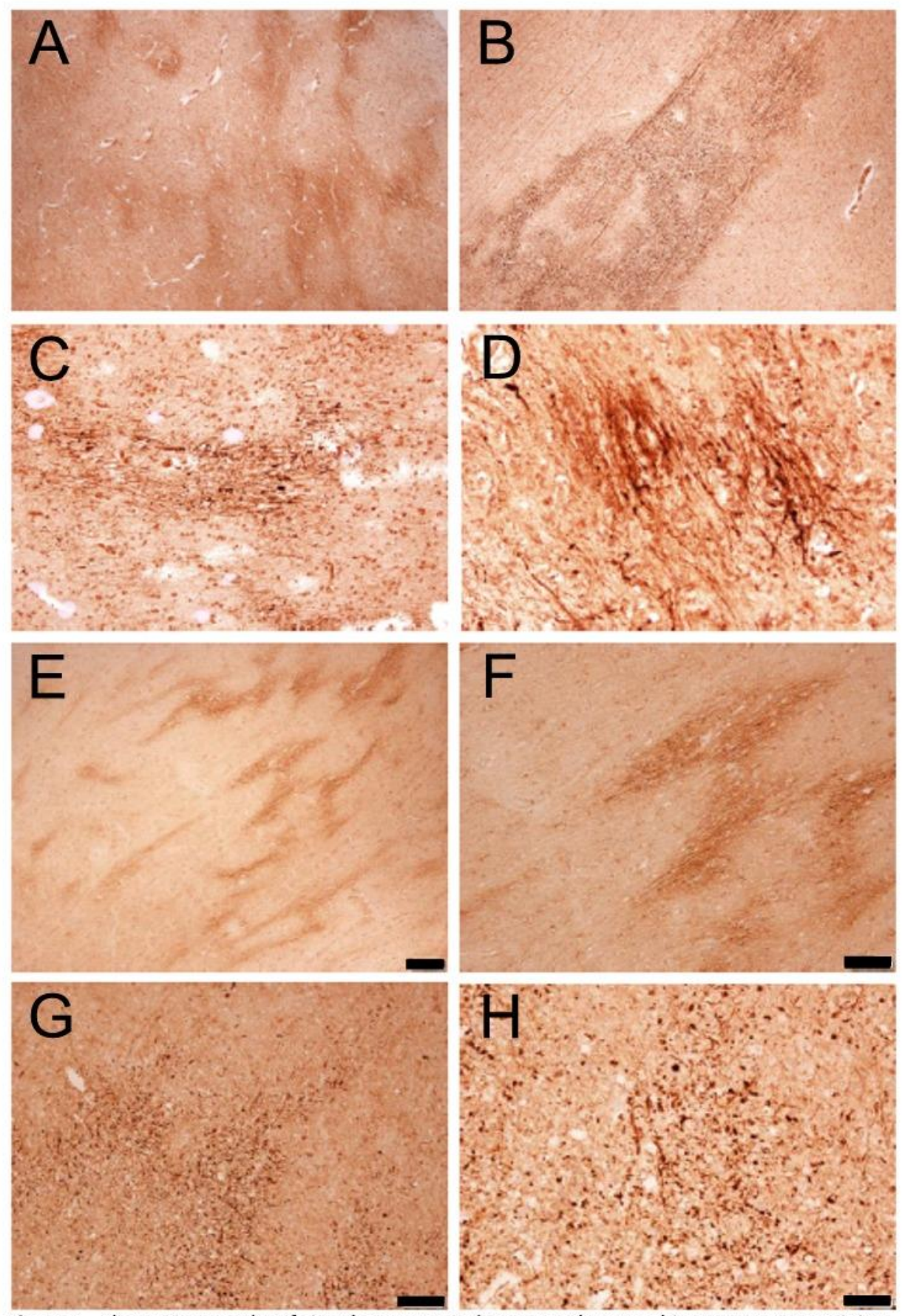

Figure 1. Photomicrographs of cingulate gyrus and precentral gyrus white matter APP staining.

A. Cingulate gyrus white matter in Case B9, a man in his 60s with COVID-19.

B. Precentral gyrus white matter in Case B8, a man in his 80s with COVID-19.

C. Precentral gyrus white matter in Case B5, a man in his 90s with COVID-19.

D. Cingulate gyrus white matter in Case B3, a woman in her 70s with COVID-19.

E. Cingulate gyrus white matter in Case $\mathrm{C5}$, a man in his 90 s with non-COVID-19 pneumonia.

F. Precentral gyrus white matter in Case C5, a man in his 90s with non-COVID-19 pneumonia.

G. Precentral gyrus white matter in Case $\mathrm{C10}$, a man in his 80 s with non-COVID-19 pneumonia.

H. Cingulate gyrus white matter in Case C10, a man in his 80 s with non-COVID-19 pneumonia.

Bar in $E$ also serves for $A=200$ um. Bar in $F$ also serves for $B=100$ um.

Bar in $\mathrm{G}$ also serves for $\mathrm{C}=50 \mathrm{um}$. Bar in $\mathrm{H}$ also serves for $\mathrm{D}=50 \mathrm{um}$. 


\section{ACKNOWLEDGEMENTS}

This project was supported by a Covid-19 Supplement to a National Institute on Aging grant, (3P30AG01961020S1), submitted in response to a Notice of Special Interest (NOSI) issued by the National Institute on Aging (NOT-AG-20-022), "to highlight the urgent need for research on Coronavirus Disease 2019...".

\section{REFERENCES}

1. Yassin, A, Nawaiseh, M, Shaban, A, et al. Neurological manifestations and complications of coronavirus disease 2019 (COVID-19): a systematic review and meta-analysis. BMC Neurol. $2021 ; 21: 138$.

2. Varatharaj, A, Thomas, N, Ellul, MA, et al. Neurological and neuropsychiatric complications of COVID19 in 153 patients: a UK-wide surveillance study. Lancet Psychiatry. 2020; 7:875-882.

3. Delamarre, L, Gollion, C, Grouteau, G, et al. COVID-19-associated acute necrotising encephalopathy successfully treated with steroids and polyvalent immunoglobulin with unusual lgG targeting the cerebral fibre network. J Neurol Neurosurg Psychiatry. 2020; 91:1004-1006.

4. Ghannam, M, Alshaer, Q, Al-Chalabi, M, et al. Neurological involvement of coronavirus disease 2019: a systematic review. J Neurol. 2020; 267:3135-3153.

5. Anand, PZLBNHDHGDMC-AAM. Neurologic Findings Among Inpatients with COVID-19 at a Safety-Net U.S. Hospital. Neurology Clin Practive. 2020; In press.

6. Kremer, S, Lersy, F, de, SJ, et al. Brain MRI Findings in Severe COVID-19: A Retrospective Observational Study. Radiology. 2020; 297:E242-E251. 
medRxiv preprint doi: https://doi.org/10.1101/2021.12.16.21266656; this version posted December 17, 2021. The copyright holder for this preprint (which was not certified by peer review) is the author/funder, who has granted medRxiv a license to display the preprint in perpetuity. It is made available under a CC-BY-NC-ND 4.0 International license .

7. Pons-Escoda, A, Naval-Baudin, P, Majos, C, et al. Neurologic Involvement in COVID-19: Cause or Coincidence? A Neuroimaging Perspective. AJNR Am J Neuroradiol. 2020; 41:1365-1369.

8. Romero-Sanchez, CM, Diaz-Maroto, I, Fernandez-Diaz, E, et al. Neurologic manifestations in hospitalized patients with COVID-19: The ALBACOVID registry. Neurology. 2020; 95:e1060e1070.

9. Ellul, MA, Benjamin, L, Singh, B, et al. Neurological associations of COVID-19. Lancet Neurol. 2020; 19:767-783.

10. Guerrero, JI, Barragan, LA, Martinez, JD, et al. Central and peripheral nervous system involvement by COVID-19: a systematic review of the pathophysiology, clinical manifestations, neuropathology, neuroimaging, electrophysiology, and cerebrospinal fluid findings. BMC Infect Dis. 2021; 21:515.

11. Deigendesch, N, Sironi, L, Kutza, M, et al. Correlates of critical illness-related encephalopathy predominate postmortem COVID-19 neuropathology. Acta Neuropathol. 2020; 140:583-586.

12. Thakur, KT, Miller, EH, Glendinning, MD, et al. COVID-19 neuropathology at Columbia University Irving Medical Center/New York Presbyterian Hospital. Brain. 2021.

13. Bhatnagar, J, Gary, J, Reagan-Steiner, S, et al. Evidence of Severe Acute Respiratory Syndrome Coronavirus 2 Replication and Tropism in the Lungs, Airways, and Vascular Endothelium of Patients With Fatal Coronavirus Disease 2019: An Autopsy Case Series. J Infect Dis. 2021; 223:752-764.

14. Roden, AC, Vrana, JA, Koepplin, JW, et al. Comparison of In Situ Hybridization, Immunohistochemistry, and Reverse Transcription-Droplet Digital Polymerase Chain Reaction for Severe Acute Respiratory Syndrome Coronavirus 2 (SARS-CoV-2) Testing in Tissue. Arch Pathol Lab Med. 2021; 145:785-796. 
medRxiv preprint doi: https://doi.org/10.1101/2021.12.16.21266656; this version posted December 17, 2021. The copyright holder for this preprint (which was not certified by peer review) is the author/funder, who has granted medRxiv a license to display the preprint in perpetuity. It is made available under a CC-BY-NC-ND 4.0 International license .

15. Sablone, S, Solarino, B, Ferorelli, D, et al. Post-mortem persistence of SARS-CoV-2: a preliminary study. Forensic Sci Med Pathol. 2021.

16. Skok, K, Stelzl, E, Trauner, M, et al. Post-mortem viral dynamics and tropism in COVID-19 patients in correlation with organ damage. Virchows Arch. 2020.

17. Deinhardt-Emmer, S, Wittschieber, D, Sanft, J, et al. Early postmortem mapping of SARS-CoV-2 RNA in patients with COVID-19 and correlation to tissue damage. bioRxiv. 2020;2020.

18. Bihlmaier, K, Coras, R, Willam, C, et al. Disseminated Multifocal Intracerebral Bleeding Events in Three Coronavirus Disease 2019 Patients on Extracorporeal Membrane Oxygenation As Rescue Therapy. Crit Care Explor. 2020; 2:e0218.

19. Freij, BJ, Gebara, BM, Tariq, R, et al. Fatal central nervous system co-infection with SARS-CoV-2 and tuberculosis in a healthy child. BMC Pediatr. 2020; 20:429.

20. Matschke, J, Lutgehetmann, M, Hagel, C, et al. Neuropathology of patients with COVID-19 in Germany: a post-mortem case series. Lancet Neurol. 2020; 19:919-929.

21. Wichmann, D, Sperhake, JP, Lutgehetmann, M, et al. Autopsy Findings and Venous Thromboembolism in Patients With COVID-19: A Prospective Cohort Study. Ann Intern Med. $2020 ; 173: 268-277$.

22. Paniz-Mondolfi, A, Bryce, C, Grimes, Z, et al. Central nervous system involvement by severe acute respiratory syndrome coronavirus-2 (SARS-CoV-2). J Med Virol. 2020; 92:699-702.

23. Menter, T, Haslbauer, JD, Nienhold, R, et al. Postmortem examination of COVID-19 patients reveals diffuse alveolar damage with severe capillary congestion and variegated findings in lungs and other organs suggesting vascular dysfunction. Histopathology. 2020; 77:198-209.

24. Al-Sarraj, S, Troakes, C, Hanley, B, et al. Invited Review: The spectrum of neuropathology in COVID19. Neuropathol Appl Neurobiol. 2020. 
medRxiv preprint doi: https://doi.org/10.1101/2021.12.16.21266656; this version posted December 17, 2021. The copyright holder for this preprint (which was not certified by peer review) is the author/funder, who has granted medRxiv a license to display the preprint in perpetuity. It is made available under a CC-BY-NC-ND 4.0 International license .

25. Jensen, MP, Le, QJ, Officer-Jones, L, et al. Neuropathological findings in two patients with fatal COVID-19. Neuropathol Appl Neurobiol. 2020.

26. Kantonen, J, Mahzabin, S, Mayranpaa, MI, et al. Neuropathologic features of four autopsied COVID-19 patients. Brain Pathol. 2020; 30:1012-1016.

27. Meinhardt, J, Radke, J, Dittmayer, C, et al. Olfactory transmucosal SARS-CoV-2 invasion as a port of central nervous system entry in individuals with COVID-19. Nat Neurosci. 2020.

28. Puelles, VG, Lutgehetmann, M, Lindenmeyer, MT, et al. Multiorgan and Renal Tropism of SARS-CoV2. N Engl J Med. 2020; 383:590-592.

29. Remmelink, M, De, MR, D'Haene, N, et al. Unspecific post-mortem findings despite multiorgan viral spread in COVID-19 patients. Crit Care. 2020; 24:495.

30. Solomon, IH, Normandin, E, Bhattacharyya, S, et al. Neuropathological Features of Covid-19. N Engl J Med. 2020; 383:989-992.

31. Lopez, G, Tonello, C, Osipova, G, et al. Olfactory bulb SARS-CoV-2 infection is not paralleled by the presence of virus in other central nervous system areas. Neuropathol Appl Neurobiol. 2021.

32. Piroth, L, Cottenet, J, Mariet, AS, et al. Comparison of the characteristics, morbidity, and mortality of COVID-19 and seasonal influenza: a nationwide, population-based retrospective cohort study. Lancet Respir Med. 2020.

33. Nannoni, S, de, GR, Bell, S, et al. Stroke in COVID-19: A systematic review and meta-analysis. Int J Stroke. $2021 ; 16: 137-149$.

34. Al-Dalahmah, O, Thakur, KT, Nordvig, AS, et al. Neuronophagia and microglial nodules in a SARSCoV-2 patient with cerebellar hemorrhage. Acta Neuropathol Commun. 2020; 8:147.

35. Bradley, BT, Maioli, H, Johnston, R, et al. Histopathology and ultrastructural findings of fatal COVID-19 infections in Washington State: a case series. Lancet. 2020; 396:320-332. 
medRxiv preprint doi: https://doi.org/10.1101/2021.12.16.21266656; this version posted December 17, 2021. The copyright holder for this preprint (which was not certified by peer review) is the author/funder, who has granted medRxiv a license to display the preprint in perpetuity. It is made available under a CC-BY-NC-ND 4.0 International license .

36. Bryce, C, Grimes, Z, Pujadas, E, et al. Pathophysiology of SARS-CoV-2: targeting of endothelial cells renders a complex disease with thrombotic microangiopathy and aberrant immune response. The Mount Sinai COVID-19 autopsy experience. medRxiv. 2020;2020.

37. Conklin, J, Frosch, MP, Mukerji, S, et al. Cerebral Microvascular Injury in Severe COVID-19. medRxiv. 2020.

38. Coolen, T, Lolli, V, Sadeghi, N, et al. Early postmortem brain MRI findings in COVID-19 non-survivors. Neurology. 2020; 95:e2016-e2027.

39. Jaunmuktane, Z, Mahadeva, U, Green, A, et al. Microvascular injury and hypoxic damage: emerging neuropathological signatures in COVID-19. Acta Neuropathol. 2020; 140:397-400.

40. Kirschenbaum, D, Imbach, LL, Rushing, EJ, et al. Intracerebral endotheliitis and microbleeds are neuropathological features of COVID-19. Neuropathol Appl Neurobiol. 2020.

41. Radmanesh, A, Raz, E, Zan, E, et al. Brain Imaging Use and Findings in COVID-19: A Single Academic Center Experience in the Epicenter of Disease in the United States. AJNR Am J Neuroradiol. 2020; 41:1179-1183.

42. Reichard, RR, Kashani, KB, Boire, NA, et al. Neuropathology of COVID-19: a spectrum of vascular and acute disseminated encephalomyelitis (ADEM)-like pathology. Acta Neuropathol. 2020; 140:1-6.

43. Song, E, Zhang, C, Israelow, B, et al. Neuroinvasion of SARS-CoV-2 in human and mouse brain. bioRxiv. 2020.

44. von Weyhern, $\mathrm{CH}$, Kaufmann, I, Neff, F, et al. Early evidence of pronounced brain involvement in fatal COVID-19 outcomes. Lancet. 2020; 395:e109.

45. Lee, MH, Perl, DP, Nair, G, et al. Microvascular Injury in the Brains of Patients with Covid-19. N Engl J Med. 2020. 
medRxiv preprint doi: https://doi.org/10.1101/2021.12.16.21266656; this version posted December 17, 2021. The copyright holder for this preprint (which was not certified by peer review) is the author/funder, who has granted medRxiv a license to display the preprint in perpetuity. It is made available under a CC-BY-NC-ND 4.0 International license.

46. Beyrouti, R, Best, JG, Chandratheva, A, et al. Characteristics of intracerebral haemorrhage associated with COVID-19: a systematic review and pooled analysis of individual patient and aggregate data. J Neurol. 2021.

47. Beyrouti, R, Adams, ME, Benjamin, L, et al. Characteristics of ischaemic stroke associated with COVID-19. J Neurol Neurosurg Psychiatry. 2020; 91:889-891.

48. Diener, HC, Berlit, P, and Masjuan, J. COVID-19: patients with stroke or risk of stroke. Eur Heart J Suppl. 2020; 22:25-28.

49. Merkler, AE, Parikh, NS, Mir, S, et al. Risk of Ischemic Stroke in Patients With Coronavirus Disease 2019 (COVID-19) vs Patients With Influenza. JAMA Neurol. 2020.

50. Nersesjan, V, Amiri, M, Christensen, HK, et al. Thirty-Day Mortality and Morbidity in COVID-19 Positive vs. COVID-19 Negative Individuals and vs. Individuals Tested for Influenza A/B: A PopulationBased Study. Front Med (Lausanne ). 2020; 7:598272.

51. Ramos-Araque, ME, Siegler, JE, Ribo, M, et al. Stroke etiologies in patients with COVID-19: the SVIN COVID-19 multinational registry. BMC Neurol. 2021; 21:43.

52. Rothstein, A, Oldridge, O, Schwennesen, $\mathrm{H}$, et al. Acute Cerebrovascular Events in Hospitalized COVID-19 Patients. Stroke. 2020; 51:e219-e222.

53. Siow, I, Lee, KS, Zhang, JJY, et al. Stroke as a Neurological Complication of COVID-19: A Systematic Review and Meta-Analysis of Incidence, Outcomes and Predictors. J Stroke Cerebrovasc Dis. $2021 ; 30: 105549$.

54. Schurink, B, Roos, E, Radonic, T, et al. Viral presence and immunopathology in patients with lethal COVID-19: a prospective autopsy cohort study. Lancet Microbe. 2020; 1:e290-e299.

55. Beach, TG, Sue, LI, Intorcia, AJ, et al. Acute Brain Ischemia, Infarction and Hemorrhage in Subjects Dying with or Without Autopsy-Proven Acute Pneumonia. medRxiv. 2021. 
medRxiv preprint doi: https://doi.org/10.1101/2021.12.16.21266656; this version posted December 17, 2021. The copyright holder for this preprint (which was not certified by peer review) is the author/funder, who has granted medRxiv a license to display the preprint in perpetuity.

It is made available under a CC-BY-NC-ND 4.0 International license .

56. Serrano, GE, Walker, JE, Arce, R, et al. Mapping of SARS-CoV-2 Brain Invasion and Histopathology in COVID-19 Disease. medRxiv. 2021.

57. Nelson, PT, Dickson, DW, Trojanowski, JQ, et al. Limbic-predominant age-related TDP-43 encephalopathy (LATE): consensus working group report. Brain. 2019; 142:1503-1527.

58. Dickson, DW, Rademakers, R, and Hutton, ML. Progressive supranuclear palsy: pathology and genetics. Brain Pathol. 2007; 17:74-82.

59. Dickson, DW, Ahmed, Z, Algom, AA, et al. Neuropathology of variants of progressive supranuclear palsy. Curr Opin Neurol. 2010; 23:394-400.

60. Crary, JF, Trojanowski, JQ, Schneider, JA, et al. Primary age-related tauopathy (PART): a common pathology associated with human aging. Acta Neuropathol. 2014; 128:755-766.

61. Kovacs, GG, Ferrer, I, Grinberg, LT, et al. Aging-related tau astrogliopathy (ARTAG): harmonized evaluation strategy. Acta Neuropathol. 2016; 131:87-102.

62. Roman, GC, Tatemichi, TK, Erkinjuntti, T, et al. Vascular dementia: diagnostic criteria for research studies. Report of the NINDS-AIREN International Workshop. Neurology. 1993; 43:250-260.

63. Mackenzie, IR, Neumann, M, Baborie, A, et al. A harmonized classification system for FTLD-TDP pathology. Acta Neuropathol. 2011; 122:111-113.

64. Gelb, DJ, Oliver, E, and Gilman, S. Diagnostic criteria for Parkinson disease. Arch Neurol. 1999; 56:3339.

65. Dickson, DW, Braak, H, Duda, JE, et al. Neuropathological assessment of Parkinson's disease: refining the diagnostic criteria. Lancet Neurol. 2009; 8:1150-1157.

66. Dickson, DW. Required techniques and useful molecular markers in the neuropathologic diagnosis of neurodegenerative diseases. Acta Neuropathol. 2005; 109:14-24. 
medRxiv preprint doi: https://doi.org/10.1101/2021.12.16.21266656; this version posted December 17, 2021. The copyright holder for this preprint (which was not certified by peer review) is the author/funder, who has granted medRxiv a license to display the preprint in perpetuity. It is made available under a CC-BY-NC-ND 4.0 International license.

67. Hyman, BT, Phelps, CH, Beach, TG, et al. National Institute on Aging-Alzheimer's Association guidelines for the neuropathologic assessment of Alzheimer's disease. Alzheimers Dement. 2012; 8:1-13.

68. Montine, TJ, Phelps, CH, Beach, TG, et al. National Institute on Aging-Alzheimer's Association guidelines for the neuropathologic assessment of Alzheimer's disease: a practical approach. Acta Neuropathol. 2012; 123:1-11.

69. McKeith, IG, Dickson, DW, Lowe, J, et al. Diagnosis and management of dementia with Lewy bodies: third report of the DLB Consortium. Neurology. 2005; 65:1863-1872.

70. Baba, Y, Ghetti, B, Baker, MC, et al. Hereditary diffuse leukoencephalopathy with spheroids: clinical, pathologic and genetic studies of a new kindred. Acta Neuropathol. 2006; 111:300-311.

71. Kalaria, RN, Bhatti, SU, Palatinsky, EA, et al. Accumulation of the beta amyloid precursor protein at sites of ischemic injury in rat brain. Neuroreport. 1993; 4:211-214.

72. MacKenzie, JM. Axonal Injury in Stroke: A Forensic Neuropathology Perspective. Am J Forensic Med Pathol. 2015; 36:172-175.

73. Hayashi, T, Ago, K, Nakamae, T, et al. Two different immunostaining patterns of beta-amyloid precursor protein (APP) may distinguish traumatic from nontraumatic axonal injury. Int J Legal Med. 2015; 129:1085-1090.

74. Ciallella, JR, Ikonomovic, MD, Paljug, WR, et al. Changes in expression of amyloid precursor protein and interleukin-1beta after experimental traumatic brain injury in rats. J Neurotrauma. 2002; 19:1555-1567.

75. Hortobagyi, T, Wise, S, Hunt, N, et al. Traumatic axonal damage in the brain can be detected using beta-APP immunohistochemistry within $35 \mathrm{~min}$ after head injury to human adults. Neuropathol Appl Neurobiol. 2007; 33:226-237. 
medRxiv preprint doi: https://doi.org/10.1101/2021.12.16.21266656; this version posted December 17, 2021. The copyright holder for this preprint (which was not certified by peer review) is the author/funder, who has granted medRxiv a license to display the preprint in perpetuity. It is made available under a CC-BY-NC-ND 4.0 International license.

76. Tomimoto, H, Lin, JX, Matsuo, A, et al. Different mechanisms of corpus callosum atrophy in Alzheimer's disease and vascular dementia. J Neurol. 2004; 251:398-406.

77. Akiguchi, I, Tomimoto, $\mathrm{H}$, Wakita, $\mathrm{H}$, et al. Topographical and cytopathological lesion analysis of the white matter in Binswanger's disease brains. Acta Neuropathol. 2004; 107:563-570.

78. Gerber, J, Seitz, RC, Bunkowski, S, et al. Evidence for frequent focal and diffuse acute axonal injury in human bacterial meningitis. Clin Neuropathol. 2009; 28:33-39.

79. Buttner, A, Rohrmoser, K, Mall, G, et al. Widespread axonal damage in the brain of drug abusers as evidenced by accumulation of beta-amyloid precursor protein (beta-APP): an immunohistochemical investigation. Addiction. 2006; 101:1339-1346.

80. Ghosh, N, DeLuca, GC, and Esiri, M. Evidence of axonal damage in human acute demyelinating diseases. J Neurol Sci. 2004; 222:29-34. 